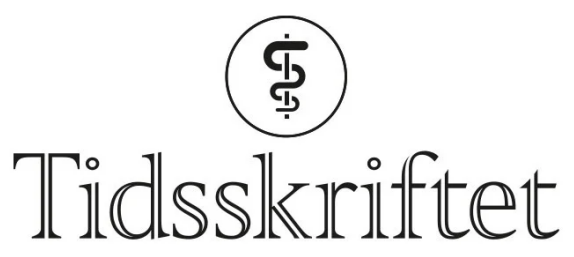

DEN NORSKE LEGEFORENING

\title{
Verdens beste kreftbehandling
}

\section{LEDER}

\section{DANIEL HEINRICH}

Daniel.Heinrich@sykehuset-innlandet.no

Daniel Heinrich er spesialist i onkologi og overlege ved Kreftavdelingen, Sykehuset Innlandet Gjøvik. Han er leder i Norsk Onkologisk Forening og medlem i Ekspertpanelet og rapportør for kreft i CPME (Comité Permanent des Médecins Européens/Standing Committee of European Doctors). Forfatteren har fylt ut ICMJE-skjemaet og oppgir følgende interessekonflikter: Han har fått forskningsst $\varnothing t t e$ fra selskapene Astra Zeneca, Bayer, Bristol-Myers Squibb, EISAI, Janssen-Cilaq, Merck Sharp \& Dome, Pfizer og Roche. Han har fått foredraghonorar fra AAA, a Novartis company, Astellas, Bayer, Bristol-Myers Squibb, Dagens Medisin, IPSEN, Janssen-Cilaq, Statens legemiddelverk, Prostatakreftforeningen, Novartis og Sanofi. Han har deltatt i advisory board for Astellas, Astra Zeneca, Bayer, EISAI, IPSEN, Janssen-Cilaq og Roche.

\section{Tilgang til moderne kreftbehandling er viktig for den generelle tillit til helsevesenet. Slik behandling byr på enorme muligheter, men også nye utfordringer.}

Tidsskriftet publiserer nå flere artikler som illustrerer hvilken vei moderne kreftbehandling er i ferd med å gå og hvilke utfordringer den stadig raskere utviklingen av nye behandlingsmetoder byr på.

Det er særlig to forhold som har ført til forbedring av resultatene innen onkologisk behandling: innføring av moderne, men fremdeles nokså lite målrettet immunterapi og stadig flere medikamenter i kategorien målrettet behandling. Det nyeste tilskuddet av behandlingsmuligheter er kombinasjonen av disse to strategiene, enten ved å bruke to medikamenter samtidig eller ved å manipulere immunceller genetisk for å gjøre dem i bedre stand til å skille mellom kreftceller og normalt vev (1).

Uttrykket persontilpasset medisin brukes ofte i sammenheng med moderne kreftmedisin. Det er ikke helt korrekt. Leger har alltid tilpasset sin behandling til den enkelte pasient. Med nyere diagnostiske metoder klarer vi imidlertid å tilpasse vår behandling mer spesifikt til pasientens individuelle sykdom. Dette er spesielt aktuelt innen medikamentell onkologisk behandling, der analyse av genetiske forandringer i kreftcellene og dermed årsaken til den enkelte pasients kreftsykdom fører til flere individuelt tilpassede behandlingsmuligheter. Samtidig blir pasientkohortene som behandles likt, mindre og mindre. I siste instans kan man tenke seg et fremtidsscenario der hver kreftpasient behandles med sitt «eget» medikament.

Dessverre byr nye muligheter seg sjelden uten at nye utfordringer også følger med. Moderne kreftbehandling er intet unntak. Selv om forholdet mellom risiko versus nytte ofte er bedre enn ved tradisjonell behandling, har også moderne kreftmedikamenter 
bivirkninger. Hvis man ikke kjenner til, påviser og behandler disse, kan følgene bli fatale, slik en av artiklene i Tidsskriftet nå viser (2). Da trenger vi dedikerte fagfolk som er utdannet til å følge med på og å håndtere slike bivirkninger.

\section{«Heldigvis skaper utfordringer også nye muligheter. Norge kan klare å bli best $i$ klassen»}

Videre krever målrettet kreftbehandling mer omfattende diagnostikk, ofte i form av genomisk testing av tumorvev. Det siste omtales gjerne som nestegenerasjonssekvensering (new generation sequencing, NGS). Denne type testing er vi langt ifra i mål med å kunne tilby til alle pasienter. Først må man selvsagt bygge opp testkapasiteten, dernest vil slik testing frembringe enorme datamengder som må analyseres og tolkes, foreløpig fremdeles av mennesker.

Hittil er det kun noen av kreftpasientene som kan ha nytte av de nye behandlingsmetodene. Noen mener at andelen er så liten som mindre enn $10 \%$, andre er mer optimistiske og tror at den allerede i dag ligger på opp mot $30 \%$ (3). For at flere pasienter skal få effekt av avansert kreftbehandling, må flere medikamenter utvikles og enda mer spesifikke tester etableres. Utviklingen av kreftbehandling går raskt - raskere enn det norske systemet for vurdering av nye metoder klarer å håndtere (4). Et mer effektivt system for å få innovative behandlingsformer for små kohorter vurdert og eventuelt godkjent på kortest mulig tid, må på plass.

Heldigvis skaper utfordringer også nye muligheter. Norge kan klare å bli best i klassen. Vi har dyktige fagpersoner og internasjonalt ledende fag- og forskningsmiljøer innen kreftbehandling. Det spirer av små og mellomstore helsenæringsbedrifter som med sine innovative løsninger evner å rette seg mot noen av utfordringene vi står overfor, særlig behovet for mer automatisering innen analyse og prøvetaking. Ikke minst bør vi tilstrebe å bli et foregangsland innen kunstig intelligens og, spesifikt for helse- og onkologisektoren, innen tolkning av analyseresultater.

Hvis fagmiljøene skal henge med i utviklingen av nye behandlingsmetoder og legemidler, må det legges til rette for flere kliniske studier, med flere pasienter enn i dag. Regjeringen og helseministeren har i år lagt frem en handlingsplan for kliniske studier (5). Den inneholder viktige mål og intensjoner. For at målene skal nås, er det helt avgjørende at det på samtlige ledelsesnivåer i norsk helsetjeneste skapes en kultur som er preget av begeistring for klinisk og basalmedisinsk forskning. Jeg er glad for at bestillingsdokumentet til helseforetakene for 2021 inneholder tydelige krav til $\emptyset \mathrm{kt}$ forskningsaktivitet (므). Jeg forventer at politikerne (uansett hvilken farge regjeringen måtte ha etter valget) følger opp dette og etterlyser levering på bestillingene sine. Det vil ha stor betydning for arbeidet med å få flest mulig norske kreftpasienter med i kliniske studier.

Norske kreftpasienter har i utgangspunktet alle muligheter til å få verdens beste behandling. At alle, uavhengig av bosted og andre faktorer, får like muligheter til avansert kreftbehandling, er et overordnet mål i det norske helsevesenet. Bare slik kan tilliten til helsevesenet sikres, en tillit som er nødvendig for gode pasientforløp.

Det krever at alle involverte parter, fra fagmiljø og akademia til pasientforeninger, myndigheter og politikere, drar i samme og riktig retning.

1. June $\mathrm{CH}, \mathrm{O}$ 'Connor RS, Kawalekar OU et al. CAR T cell immunotherapy for human cancer. Science 2018; 359: 1361-5. [PubMed][CrossRef] 
2. Ragnum HB, De Bortoli AM, Elsais A et al. En mann i 6o-årene med dyspné etter immunterapi. Tidsskr Nor Legeforen 2021; 141. doi: 10.4045/tidsskr.21.0139. [CrossRef]

3. Ree AH. Presisjonsmedisin ved kreft - førebels føremålstenleg for dei få. Tidsskr Nor Legeforen 2021; 141. doi: 10.4045/tidsskr.20.0980. [PubMed][CrossRef]

4. Nye Metoder. Om systemet. https://nyemetoder.no/om-systemet Lest 19.8.2021.

5. Nasjonal handlingsplan for klinisk studier. Oslo: Helse- og omsorgsdepartementet, 2021. https://www.regjeringen.no/contentassets/59ffc7b38a4f46fbbo62aecae50e272d/207035_kliniske_studi er_k6_b.pdf Lest 19.8.2021.

6. Regjeringen. Oppdragsdokument. https://www.regjeringen.no/no/tema/helse-ogomsorg/sykehus/styringsdokumenter1/oppdragsdokument/id535564/ Lest 19.8.2021.

Publisert: 6. september 2021. Tidsskr Nor Legeforen. DOI: 10.4045/tidsskr.21.06o2

(C) Tidsskrift for Den norske legeforening 2023. Lastet ned fra tidsskriftet.no 26. april 2023. 